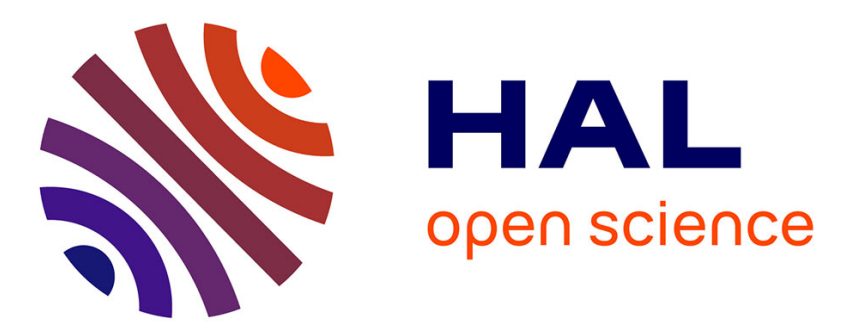

\title{
Local pH changes triggered by photoelectrochemistry for silica condensation at the liquid-liquid interface
} \author{
Lukasz Poltorak, Marc Hébrant, Mohana Afsharian, Mathieu Etienne,
} Grégoire Herzog, Alain Walcarius

\section{- To cite this version:}

Lukasz Poltorak, Marc Hébrant, Mohana Afsharian, Mathieu Etienne, Grégoire Herzog, et al.. Local $\mathrm{pH}$ changes triggered by photoelectrochemistry for silica condensation at the liquid-liquid interface. Electrochimica Acta, 2016, 188, pp.71-77. 10.1016/j.electacta.2015.11.107 . hal-01504769

\section{HAL Id: hal-01504769 \\ https://hal.univ-lorraine.fr/hal-01504769}

Submitted on 9 Nov 2018

HAL is a multi-disciplinary open access archive for the deposit and dissemination of scientific research documents, whether they are published or not. The documents may come from teaching and research institutions in France or abroad, or from public or private research centers.
L'archive ouverte pluridisciplinaire HAL, est destinée au dépôt et à la diffusion de documents scientifiques de niveau recherche, publiés ou non, émanant des établissements d'enseignement et de recherche français ou étrangers, des laboratoires publics ou privés. 


\title{
Local pH changes triggered by photoelectrochemistry for silica condensation at the liquid-liquid interface
}

Lukasz Poltorak, Marc Hébrant, Mohana Afsharian, Mathieu Etienne, Grégoire Herzog,* Alain Walcarius

Laboratoire de Chimie Physique et Microbiologie pour l'Environnement (LCPME), UMR 7564, CNRS Université de Lorraine, 405 rue de Vandoeuvre, Villers-lès-Nancy, F-54600, France.

Email:gregoire.herzog@univ-lorraine.fr; Phone: + 33383685262

This document is a postprint. Final version has been published in Electrochimica Acta, 2016, 188, 7177 (https://doi.org/10.1016/i.electacta.2015.11.107).

\begin{abstract}
We present here a new photoelectrochemical method for varying the $\mathrm{pH}$ locally to trigger silica condensation at the interface between two immiscible electrolyte solutions (ITIES). Trimethylbenzhydrylammonium cation is a photoactive compound dissolved in the organic phase. Electrochemical studies have shown a reversible transfer across the interface controlled by diffusion. Its transfer from the organic to the aqueous phase and its concomitant photo-irradiation has led to the decrease of $\mathrm{pH}$, which was locally monitored by $\mathrm{Pt}$ microelectrode covered with iridium oxide and positioned at a distance of $1 \mu \mathrm{m}$ from the ITIES by shearforce detection. Such local measurements of the $\mathrm{pH}$ were necessary as side reactions at the aqueous counter electrode were changing the bulk $\mathrm{pH}$. The $\mathrm{pH}$ at the interface dropped from 6 to lower than 2 when photoelectrolysis was applied for 50 min. This local pH variation was then harnessed to the acidic condensation of mesoporous silica at the ITIES.
\end{abstract}

Keywords: Ion-transfer voltammetry, ITIES, quaternary ammonium, interfacial modification, electrochemically assisted sol-gel deposition. 


\section{Introduction}

Controlling the properties of the interface between two immiscible electrolyte solutions (ITIES) have interest in the domains of catalysis [1] or electroanalysis [2]. The ITIES can be modified by either insitu synthesis or by the assembly at the liquid-liquid interface of objects (e.g. nanoparticles or membranes) synthesised ex-situ. Membranes prepared ex-situ have been used for size or charge selectivity [3-5] or improved sensitivity [6-8]. Senthilkumar et al. synthesised a zeolite $Y$, which modified the interface and presented both size exclusion of tetrabutylammonium cations and charge exclusion of tetrafluoroborate and perchlorate anions [3]. Chen and colleagues prepared mesoporous silica supported by a polyethylene terephthalate membrane [9], which was then used for the detection of folic acid at the ITIES [5]. Sensitivity of electroanalysis at the ITIES was improved by the use of regularly aligned ITIES of micro- [6,7] or nanoscopic dimensions [8] supported by polymeric [6] or silicon membranes $[7,8]$. Another example of ex-situ preparation strategy was the self-assembly of gold nanoparticles at the ITIES to investigate thermodynamic and kinetic aspects of interfacial redox catalysis [10]. In-situ preparation strategies involved the electrochemical synthesis of metallic nanoparticles [11-15] or of silica deposits [16-21]. In the case of in-situ modification of the ITIES, the two reactants are present in separate phases and are brought into contact by tuning the interfacial potential difference. Metallic salts are present in one phase and a reducing agent in the other. When both are present at the interface, metallic salts are reduced to form nanoparticles, whose dimensions will depend on the experimental conditions (e.g. interfacial potential difference applied, interfacial tension and $\mathrm{pH}$ of the solution [22-24]). Toth et al. used a combination of both ex-situ and in-situ strategies for the decoration of graphene flakes with gold nanoparticles on side of the graphene sheet and with palladium nanoparticles on the other side [25]. Surfactant templated mesoporous silica can also be electrogenerated at the ITIES by ion transfer voltammetry [16-21]. Silica precursor (e.g. tetraethoxysilane, TEOS) is present in the aqueous phase, while the template cation (e.g. cetyltrimethylammonium, $\mathrm{CTA}^{+}$) is dissolved in the organic phase [18-21]. The transfer of $\mathrm{CTA}^{+}$to the aqueous phase catalyses the self-assembled condensation of silica, arising from favourable electrostatic interactions between surfactant cations and silanolate species. As for the ex-situ preparation strategy, in-situ modification of the ITIES can be used for electrocatalysis [14] or with the aim of achieving charge and size selectivity [21].

Another approach for the modification of the ITIES consists of tuning the interfacial pH to trigger a chemical reaction. This method is already used for the electrochemically assisted generation of mesoporous silica and layered double hydroxide materials at the solid-liquid interface [26]. Niedziolka and Opallo reported the deposition of silica at a three phase junction, which was electrochemically 
assisted [27]. An indium tin oxide electrode was immersed in a biphasic system made of an organic phase with a silica precursor and a sulphite aqueous solution. An anodic potential was applied at the indium tin oxide electrode, which resulted in the oxidation of sulphite to sulphate and the electrochemical generation of protons. At the three phase junction, protons hydrolysed the silanes, which condensed on the electrode. Based on these previous experiments, we suggest to deposit silica at the ITIES by tuning the interfacial pH electro- and photochemically.

We present here a new photoelectrochemical method for varying the interfacial $\mathrm{pH}$ to trigger silica condensation at the ITIES. Trimethylbenzhydrylammonium $\left(\mathrm{PH}^{+}\right)$cation is a photoactive compound dissolved in the organic phase, which ion transfer was investigated by cyclic voltammetry. The impact of its photodegradation on the interfacial pH was investigated using a Pt microelectrode covered with iridium oxide as a pH probe. The local pH variation was then harnessed to the acidic condensation of silica at the ITIES.

\section{Experimental section}

\section{Materials and reagents}

Bis(triphenylphosphoranyldiene) ammonium chloride, (BTPPA ${ }^{+} \mathrm{Cl}^{-}, 97 \%$, Aldrich) and potassium tetrakis(4-chlorophenylborate), ( $\mathrm{K}^{+} \mathrm{TPBCl}$, $\geq 98 \%$, Fluka), were used to prepare the organic electrolyte by metathesis reaction. Aminodiphenylmethane hydrochloride (ADPM, 97\%, Aldrich) was used to prepare trimethylbenzhydrylammonium iodide $\left(\mathrm{PH}^{+} \mathrm{I}^{-}\right)$by methylation reaction with iodomethane $\left(\mathrm{CH}_{3} \mathrm{l}, 99.5 \%\right.$, Aldrich). Other reagents used during methylation reaction are: anhydrous sodium carbonate ( $\mathrm{Na} 2 \mathrm{CO} 3, \geq 99.9 \%$, Merck), potassium iodide ( $\mathrm{KI}, 99 \%$, SDS), sodium thiosulfate $\left(\mathrm{Na}_{2} \mathrm{~S}_{2} \mathrm{O}_{3}\right.$, >99\%, Labosi) and dichloromethane $\left(\mathrm{CH}_{2} \mathrm{Cl}_{2}, \geq 99.9 \%\right.$, Carlo Erba reagents). Trimethylbenzhydrylammonium tetrakis(4-chlorophenylborate) $\left(\mathrm{PH}^{+} \mathrm{TPBCl}\right)$ was synthesiszed by methathesis of $\mathrm{PH}^{+} \mathrm{I}^{-}$and $\mathrm{K}^{+} \mathrm{TPBCl}$. Sodium chloride, $(\mathrm{NaCl}, \geq 98 \%$, Prolabo) was used as the aqueous phase electrolyte. Silica precursor used in this study was tetraethoxysilane (TEOS, 98\%, Alfa Aesar) and the soft template was cetyltrimethylammonium bromide (CTAB, $\geq 99 \%$, Acros Organic). The high density organic phase was a 1.2-dichloroethane (DCE, $\geq 99 \%$, Sigma-Aldrich) whereas the low density phase was high purity $\mathrm{H}_{2} \mathrm{O}$ obtained from a Millipore milli-Q water purification system. Ferric chloride hexahydrate $\left(\mathrm{FeCl}_{3} \cdot 6 \mathrm{H}_{2} \mathrm{O}, 99-102 \%\right.$, Fluka) was used to prepare silver/silver chloride reference electrodes.

\section{Synthesis of $\mathrm{PH}^{+} \mathrm{TPBCl}^{-}$}


Trimethylbenzhydrylammonium tetrakis(4-chlorophenylborate) $\left(\mathrm{PH}^{+} \mathrm{TPBCl}\right.$ ) is the chemical selected to control the interfacial pH. First, $\mathrm{PH}^{+} l^{-}$is synthesised following the procedure published elsewhere [28]. Aminodiphenylmethane $(1 \mathrm{~g})$, anhydrous sodium carbonate $(3.85 \mathrm{~g})$ and iodomethane $(2.26 \mathrm{~mL})$ are added to $100 \mathrm{~mL}$ of de-oxygenated methanol. The solution is refluxed for 24 hours at $80^{\circ} \mathrm{C}$ under nitrogen. After the mixture has cooled down to room temperature, $30 \mathrm{~mL}$ of $1 \mathrm{M}$ sodium thiosulfate is added and the mixture is stirred for 15 minutes. Insoluble part of reaction mixture is filtered. $10 \mathrm{~g}$ of potassium iodide is added and the reaction mixture is stirred for another 15 minutes. The reaction mixture is transferred to a separating funnel. $50 \mathrm{~mL}$ of $\mathrm{H}_{2} \mathrm{O}$ and $50 \mathrm{~mL}$ of dichloromethane are added. After extraction, the organic phase is collected. This extraction step is repeated twice more by the addition of $50 \mathrm{~mL}$ of dichloromethane. $\mathrm{PH}^{+} \mathrm{I}^{-}$is collected after dichloromethane evaporation. The ${ }^{1} \mathrm{H}$ NMR spectrum for $\mathrm{PH}^{+}{ }^{-}$in DMSO at $300 \mathrm{MHz}$ is recorded. The chemical shifts were $\delta=7.9 \mathrm{ppm}(\mathrm{m}, 4$ $\mathrm{H})$ and $\delta=7.5 \mathrm{ppm}(\mathrm{m}, 6 \mathrm{H}), \delta=6.0 \mathrm{ppm}(\mathrm{s}, 1 \mathrm{H})$ and $\delta=3.1 \mathrm{ppm}(\mathrm{s}, 9 \mathrm{H})$. The chemical shifts are in good agreement with the values reported [28]. The absence of chemical shifts at $9.2 \mathrm{ppm}$ confirms that the amine groups of the initial reagent aminodiphenylmethane have all been methylated. $\mathrm{PH}^{+} \mathrm{TPBCl}^{-}$was then obtained by the metathesis of $\mathrm{PH}^{+} \mathrm{I}^{-}$and $\mathrm{K}^{+} \mathrm{TPBCl}^{-}$. Equimolar amounts of $\mathrm{PH}^{+} \mathrm{l}^{-}$ $(0.500 \mathrm{~g})$ and $\mathrm{K}^{+} \mathrm{TPBCl}^{-}(0.740 \mathrm{~g})$ are dissolved separately in $10 \mathrm{~mL}$ and $20 \mathrm{~mL}$ of $1: 2$ mixture of $\mathrm{H}_{2} \mathrm{O}: \mathrm{MeOH}$. The solution of $\mathrm{PH}^{+} \mathrm{l}^{-}$is added drop-wise to a vigorously stirring solution of $\mathrm{K}^{+} \mathrm{TPBCl}^{-}$ resulting in white precipitate. The reaction is continuously stirred at $4^{\circ} \mathrm{C}$ for $48 \mathrm{~h}$. The white precipitate is filtered under vacuum for $30 \mathrm{~min}$. In order to purify the product from $\mathrm{KI}$, it is rinsed three times with $10 \mathrm{~mL}$ of distilled water (iodide detection is followed with ion chromatography). The product is centrifuged (15 minutes at $5000 \mathrm{rpm}$ ). The product is dried under a vacuum pump and then transferred to a desiccator overnight. $\mathrm{PH}^{+} \mathrm{TPBCl}^{-}$is dissolved in acetone and then filtered under gravity using filter paper and left to recrystallize. $\mathrm{PH}^{+} \mathrm{TPBCl}$ is a viscous liquid difficult to handle, it is thus dissolved in dichloroethane. Solution is stored at $4^{\circ} \mathrm{C}$.

\section{Electrochemical set-up}

Two electrochemical set-ups were used: (i) a custom-made borosilicate glass cell for cyclic voltammetry experiments; (ii) a SECM setup for $\mathrm{pH}$ measurements. For cyclic voltammetry, a fourelectrode set-up was used: a platinum mesh and a $\mathrm{Ag} / \mathrm{AgCl}$ wire were used as counter and reference electrodes in each phase. The interfacial surface area was $2.86 \mathrm{~cm}^{2}$. The electrochemical cells used were:

Cell 1: Ag |AgCl|5 mM NaCl (aqueous) | |x mM PH+TPBCl in $10 \mathrm{mM} \mathrm{BTPPA}^{+} \mathrm{TPBCl}^{-}(1,2-\mathrm{DCE}) \mid 10 \mathrm{mM} \mathrm{LiCl}$ $+10 \mathrm{mM} \mathrm{BTPPA}^{+} \mathrm{Cl}^{-}$(aqueous) $|\mathrm{AgCl}| \mathrm{Ag}$ 
Cell 2: $\mathrm{Ag}|\mathrm{AgCl}|$ y mM CTAB $+5 \mathrm{mM} \mathrm{NaCl}$ (aqueous) || x mM PH ${ }^{+} \mathrm{TPBCl}^{-}$in $10 \mathrm{mM} \mathrm{BTPPA}^{+} \mathrm{TPBCl}^{-}+20 \%$ v/v TEOS (1,2-DCE)|10 mM LiCl + $10 \mathrm{mM} \mathrm{BTPPA}^{+} \mathrm{Cl}^{-}$(aqueous) |AgCl|Ag

The second experimental set-up was used for the $\mathrm{pH}$ measurements. It was a custom-made SECM setup adapted from the instrument developed by Sensolytics (Bochum, Germany) [29-32]. The pH was measured locally by potentiometry using a Pt microelectrode modified with iridium oxide and connected to a Keithey 6430 high impedance potentiometer. The microelectrode position was positioned at $1 \mu \mathrm{m}$ from the interface with shearforce detection by using two piezoelectric plates (Piezomechanik Pickelmann, München, Germany) attached to the electrode and electrically connected to a lock-in amplifier (Signal Recovery, model 7280) [33]. The liquid-liquid interface was supported by a silicon membrane (100 $\mu \mathrm{m}$ thick) pierced with an array of 8 pores $(\varnothing=50 \mu \mathrm{m})$ arranged in a hexagonal compact structure. The pore center to center distance was $500 \mu \mathrm{m}$. The sensitive frequencies used to position the microelectrode tip at a distance of $1 \mu \mathrm{m}$ from the silicon wafer were between 170 and $270 \mathrm{kHz}$, the microelectrode was then moved over the liquid-liquid interface. A similar set-up was already used for scanning electrochemical microscopy measurements [29,31,32]. The iridium oxide pH probe was then used with a liquid-liquid electrochemical cell and a mercury short-arc lamp (120 W) as an irradiation source (HXP 120 UV lamp from LOT-Oriel). In the case of macroscopic liquid-liquid cells, both organic and aqueous solutions were illuminated, whereas the SECM set-up was illuminated from the aqueous side as illustrated in Figure 1.

\section{Preparation of the $\mathrm{pH}$ probe}

Electrodes were prepared according to a protocol previously described [34]. A $25 \mu \mathrm{m}$ diameter platinum wire (purity 99.9\%; hard, Goodfellow SARL, France) was inserted and pulled in a quartz capillary using Laser Puller (P-2000; Sutter Instrument Company, USA). The Pt wire was electrically connected with a copper wire covered by a conducting epoxy resin (EPO-TEK $\left.{ }^{\circledR}\right)$ before treatment at 80 ${ }^{\circ} \mathrm{C}$ for $2 \mathrm{~h}$. The electrodes have been polished on silicon carbide films (Struers, Denmark). The solution for iridium oxide deposition was prepared following a previous report from Yamanaka [35]. $0.15 \mathrm{~g} \mathrm{IrCl} 4$ ( $\geq 99.9 \%$, Aldrich), $1 \mathrm{~mL}$ of $\mathrm{H}_{2} \mathrm{O}_{2} 30 \% \mathrm{w} / \mathrm{w}$ (Acros organics), and $0.5 \mathrm{~g}$ of oxalic acid dehydrate (99\%, Rectapur) were added slowly under stirring to $100 \mathrm{~mL}$ of water within a period of 60 minutes. Potassium carbonate (Merck) was then added to adjust the $\mathrm{pH}$ at 10.5 , leading to a pale yellow solution. This solution was left at room temperature for $48 \mathrm{~h}$. The resulting pale blue solution was then stored at $4{ }^{\circ} \mathrm{C}$ before use. Electrodeposition of Iridium oxide was performed by cyclic voltammetry at a scan rate of $50 \mathrm{mV} \mathrm{s}^{-1}$ from 0 to $1.3 \mathrm{~V} .10$ cycles was typically used. The electrode was calibrated between $\mathrm{pH} 4$ and 7, before and after the experiment. A drift of $0.2 \mathrm{pH}$ unit was observed between the two sets of calibration. 


\section{Instrumentation}

Electrochemical experiments were either run with a PGSTAT 302N from Autolab (Metrohm, Switzerland) or with a EMStat ${ }^{3+}$ from Palm Instruments BV (Houten, Netherlands) connected to a differential electrode amplifier to accommodate the four-electrode cell.

Advances of the $\mathrm{PH}^{+}$photolysis was followed by high performance liquid chromatography. The mobile phase was made of $40 \%$ acetonitrile, $60 \%$ aqueous buffer (water: phosphate buffer (pH 7.1) v/v 5:1), and the stationary phase was a Chromolith ${ }^{\circledR}$ Performance column (RP18e 100-4.6 mm). UV detection was set at $220 \mathrm{~nm}$ and the mobile phase flow rate was $3 \mathrm{~mL} \mathrm{~min}{ }^{-1}$. Photodegradation products were analysed by mass spectrometry using a MicrOTOF-Q (Bruker). The samples were introduced by electrospray ionisation.

\section{Results and Discussion}

\section{Interfacial pH control by photoelectrochemistry at the ITIES}

After metathesis, $\mathrm{PH}^{+} \mathrm{TPBCl}^{-}$was dissolved in the organic phase and its electrochemical behaviour was investigated (Figure 2). $\mathrm{PH}^{+}$transferred from the organic to the aqueous phase at a potential $\mathrm{E}^{1 / 2}=+$ $0.31 \mathrm{~V}$. The peak to peak separation, $\Delta \mathrm{E}$, was $54 \mathrm{mV}$ (i.e. not far from the expected value of $59 \mathrm{mV}$ ) and the ratio between the forward and the reverse peak currents was close to unity. The peak current increased linearly with the square root of the scan rate for the range of scan rates between 5 and 25 $\mathrm{mV} \mathrm{s}^{-1}$ (Figure 2B). These results indicate that the transfer of $\mathrm{PH}^{+}$is a reversible and diffusion-controlled process. The diffusion coefficient for $\mathrm{PH}^{+}$in the organic phase was calculated to be $D=6.76 \times 10^{-6} \mathrm{~cm}^{2}$ $\mathrm{s}^{-1}$ from the Randles-Sevčik equation (Eq. 1): [36]

$$
i_{p}=\left(2.69 \times 10^{5}\right) z^{3 / 2} A D^{1 / 2} C v^{1 / 2}
$$

where $i / v^{1 / 2}$ (as the slope of the plot in Figure $2 \mathrm{~B}$ ) is $-9.90 \times 10^{-5} \mathrm{~A} \mathrm{~s}^{1 / 2} \mathrm{~V}^{-1 / 2}, z=+1 ; A=2.83 \mathrm{~cm}^{2}$ and $C=$ $50 \times 10^{-9} \mathrm{~mol} \mathrm{~cm}^{-3}$. The electrochemical behaviour of $\mathrm{PH}^{+}$confirms that its presence in the aqueous phase can be controlled by electrochemistry at the ITIES. $\mathrm{PH}^{+}$is a photochemically active molecule whose degradation can be responsible for $\mathrm{pH}$ changes [28].

In order to confirm that $\mathrm{PH}^{+}$can be used to tune the interfacial $\mathrm{pH}$, a series of experiments was designed to measure the $\mathrm{pH}$. An experimental set-up, based on a Pt microelectrode, modified with iridium oxide, serving as a $\mathrm{pH}$ probe, was designed to measure by potentiometry the $\mathrm{pH}$ changes caused by the photoelectrochemistry of $\mathrm{PH}^{+}$at the liquid-liquid interface (Figure 1). Two 
electrochemical circuits are set: (i) a potentiometric cell made of an iridium oxide $\mathrm{pH}$ probe and a reference electrode; (ii) a potentiostatic cell with reference and counter electrodes in the aqueous phase and a silver/silver chloride acting as both a counter and a reference electrode for the organic phase. The $\mathrm{pH}$ probe is connected to a piezoelectric module for accurate positioning using shearforce detection. The initial $\mathrm{pH}$ of the bulk solution was measured at $\mathrm{pH}$ 6.5. The ion transfer of $\mathrm{PH}^{+}$was controlled by the application of an interfacial potential difference $\Delta \mathrm{E}=+0.15 \mathrm{~V}$ and the irradiation lamp was switched on for a period of 70 minutes. For $\mathrm{pH}$ measurements during the photoelectrochemical experiments, the iridium oxide probe was positioned $1 \mu \mathrm{m}$ above the interface. The $\mathrm{pH}$ measured locally was plotted as a function of time (Figure 3). The $\mathrm{pH}$ dropped from $\mathrm{pH} 6.5$ down to $\mathrm{pH}<2$ after 70 minutes. Once the interfacial potential difference was set back at open-circuit potential and the irradiation lamp was switched off, the $\mathrm{pH}$ probe was moved back to the bulk of the solution where the $\mathrm{pH}$ was measured at $\mathrm{pH} 7.5$, indicating that only the $\mathrm{pH}$ at the interface was decreased. A calibration curve of the $\mathrm{pH}$ probe was recorded before and after each series of photoelectrochemical experiments (Inset of Figure 3). The calibration curve showed little variation confirming that the $\mathrm{pH}$ probe was still operational. A control experiment was run in the absence of $\mathrm{PH}^{+}$in the organic phase. The $\mathrm{pH}$ at the interface remained around $\mathrm{pH} 6$ for the duration of the experiment confirming that the photodegradation of $\mathrm{PH}^{+}$is responsible for the $\mathrm{pH}$ variation. Figure 4 shows the $\mathrm{pH}$ of the bulk aqueous phase after a series of potentiostatic experiments at various applied potentials held for 150 and $420 \mathrm{~s}$ in the absence of $\mathrm{PH}^{+}$. When positive potential differences was applied, $(0.0<\Delta \mathrm{E}<+0.4 \mathrm{~V})$, the $\mathrm{pH}$ of the bulk aqueous phase remained at the initial value of $\mathrm{pH} 6$. However, when negative potentials were applied $(-0.4<\Delta \mathrm{E}<0.0 \mathrm{~V})$, a significant rise of the bulk $\mathrm{pH}$ values was observed. The $\mathrm{pH}$ changes were obtained indifferently in the absence or in the presence of $\mathrm{PH}^{+}$, suggesting that $\mathrm{pH}$ changes were due to another phenomenon. Phenolphthalein was added to the aqueous phase as a $\mathrm{pH}$ indicator (colourless at $\mathrm{pH}<7$, it shows a dark purple colour at $\mathrm{pH}>8$ ). When the potential difference was held at $+0.4 \mathrm{~V}$, no colour change was observed in the aqueous phase, whereas the aqueous solution turned purple near the counter electrode at $\Delta \mathrm{E}=-0.4 \mathrm{~V}$ (inset of Figure 4). The $\mathrm{pH}$ changes monitored in the bulk were due to the generation of $\mathrm{OH}^{-}$ions when negative potentials were applied, demonstrating the need for local measurement of $\mathrm{pH}$ to monitor interfacial processes. The counter electrode must be placed far from the interface to avoid contamination by the side reactions.

In order to determine the mechanism of the $\mathrm{pH}$ changes, $\mathrm{PH}^{+}$photolysis products after ion transfer were investigated by HPLC (Figure 5) and mass spectrometry. $\mathrm{PH}^{+}$ions were transferred from the organic phase to the aqueous phase, under irradiation, at a potential difference of $+0.15 \mathrm{~V}$ for $50 \mathrm{~min}$. At the end of the photoelectrochemical experiment, the aqueous phase was collected and injected in the HPLC column. The main peak of the chromatogram (Figure 5, red curve) was measured at 2.26 min; 
a series of smaller chromatographic peaks was seen between 0.5 and 3 minutes and a small hump at 14 min of retention time. The injection of commercial diphenylmethanol into the chromatographic column confirmed that it is the main product of the photolysis (Figure 5 , dotted curve). The injection of non-photodegraded $\mathrm{PH}^{+}$showed a peak at 12.28 min (Figure 5, black curve), suggesting that almost all of $\mathrm{PH}^{+}$ions were photodegraded in $50 \mathrm{~min}$ and that the small hump at $14 \mathrm{~min}$ correspond to unreacted $\mathrm{PH}^{+}$ions. As a control experiment, an electrochemical cell was set without $\mathrm{PH}^{+}$ions in the organic phase; the potential was set at the same potential of $+0.15 \mathrm{~V}$ for $50 \mathrm{~min}$. The aqueous phase collected was injected and only the peaks before $3 \mathrm{~min}$ of retention time were observed. They could then be attributed to the degradation products of the organic electrolyte cations that might have transferred during the photoelectrochemical experiment (Inset of Figure 5). These experiments confirmed that $\mathrm{PH}^{+}$is photodegraded into one main product following its transfer controlled by electrochemistry. The aqueous phase after photolysis was analysed by mass spectrometry. The most abundant cation present was seen as $m / z=167.086$ arbitrary mass units (a.m.u.). This peak is attributed to the diarylmethyl cation, resulting from diphenylmethanol that has lost a hydroxyl group during the ionization process. A weak signal at $m / z=226.158$ a.m.u. was attributed to un-degraded $\mathrm{PH}^{+}$remaining in the solution. The presence of $\mathrm{BTPPA}^{+}$in the aqueous phase gave a non-negligible peak at $m / z=538.186$ a.m.u.

Based on these experiments, $\mathrm{PH}^{+}$is transferred from the organic to the aqueous phase, where they are photodegraded to form a carbocation, which reacts with water to give diphenylmethanol, one proton and other products derived from trimethylamine. These findings are in agreement with the literature $[28,37]$. The reaction rate between water molecules and diarylmethyl cation was previously determined to be $1.3 \times 10^{8} \mathrm{M}^{-1} \mathrm{~s}^{-1}$ [37], indicating that diphenylmethanol is formed very rapidly after the C-N bond is cleaved. It is unlikely that trimethylamine (pKa 9.70 [38]) would be formed predominantly as it would react readily with the proton to form trimethylammonium ions and would then determine the $\mathrm{pH}$. It is more likely that trimethylamine radicals are formed during the photolysis and that they recombine with other organic molecules present, from either the organic electrolyte salt or from dichloroethane molecules dissolved in the aqueous phase. The $\mathrm{pH}$ of the aqueous phase is then determined by the protons released by the photoelectrochemical reaction (Scheme 1). This could explain the drop of $\mathrm{pH}$ from slightly acidic conditions $(\mathrm{pH}$ around 6.2 before the photoelectrochemistry) to more acidic conditions (i.e. pH 3-4 after photoelectrochemistry) but not down to values as low as $\mathrm{pH}$ 1. There are several explanations possible to such a large $\mathrm{pH}$ drop (i) the lack of stability of the iridium oxide $\mathrm{pH}$ electrode at $\mathrm{pH}<2$; (ii) the fact that the irradiation might also occur in the organic phase. The potentiometric response of iridium oxide electrodes are stable at $\mathrm{pH}$ ranging from 2 to 12 [39] and hence might not be suitable to measure $\mathrm{pH}$ values lower than 2 . It might 
contribute to overestimate the $\mathrm{pH}$ value, although it cannot alone explain this value of $\mathrm{pH} 1$. Another explanation can be the irradiation of $\mathrm{PH}^{+}$in the organic phase, reacting with water molecules dissolved in the organic phase and thus releasing protons which would transfer spontaneously to the aqueous phase (Scheme 1). This was confirmed by the irradiation of a macroscopic electrochemical cell 1 at open circuit potential for 60 minutes. As a result, the bulk pH dropped from 5.5 to 3.5. In addition, the $\mathrm{CVs}$ of $\mathrm{PH}^{+}$before and after irradiation for 40 minutes are shown in Figure 6. The electrochemical cell was at open circuit potential during the irradiation. The peak currents measured for the $\mathrm{PH}^{+}$transfer dropped from $129.6 \mu \mathrm{A}$ to $69.3 \mu \mathrm{A}$ (for the forward scan) and from 131.4 $\mu \mathrm{A}$ down to $44.5 \mu \mathrm{A}$ (for the reverse scan) indicating that $\mathrm{PH}^{+}$ions were photodegraded. Furthermore, a strong background current is recorded at the positive end of the potential window, which is consistent with a significant increase of proton concentration in the aqueous phase. The resulting protons are then transferred spontaneously to the aqueous phase and thus contribute to further decreasing the $\mathrm{pH}$ (Scheme 1). Since the changes of local $\mathrm{pH}$ were significant enough, the photoelectrochemistry of $\mathrm{PH}^{+}$was then used to trigger the hydrolysis and condensation of TEOS at the liquid-liquid interface.

\section{Photoelectrochemically induced generation of mesoporous silica at the ITIES}

Previous works have shown that silica can be electrodeposited at the ITIES by the transfer of cationic surfactant (e.g. cetyltrimethylammonium) from the organic phase to the aqueous phase containing hydrolyzed silica precursor [18-21]. The surfactant ion acts both as a catalyst for silica condensation and as a structure driving agent. Liquid - liquid interfaces can also be modified with silica using a reversed system where the precursor (i.e. TEOS) is dissolved in the organic phase and the surfactant (i.e. $\mathrm{CTA}^{+} \mathrm{Br}^{-}$) in the aqueous phase $[27,40]$. TEOS is only hydrolyzed at the interface where it is in contact with protons from the aqueous phase and then condensation can occur. Niedziolka and Opallo investigated the electrochemically assisted sol-gel process at a three phase junction [27]. An indium tin oxide electrode was immersed in a biphasic system, which consisted in a sulphite aqueous solution and an octyltriethoxysilane solution in nitrobenzene. The oxidation of sulphite at the ITO electrode led to the electrogeneration of protons, which caused the silane hydrolysis at the interface and eventually the deposition of a strip of silica at the three phase junction by the means of an acidic condensation. In our case, the biphasic system consisted of a $5 \mathrm{mM} \mathrm{NaCl}$ solution and of an organic solution containing $0.5 \mathrm{mM} \mathrm{PH}^{+} \mathrm{TPBCl}^{-}$in $8 \mathrm{mM} \mathrm{BTPPA}^{+} \mathrm{TPBCl}^{-}$in $80 \%$ dichloroethane and $20 \%$ TEOS (Electrochemical cell 2). Figure 7 shows the CVs in the absence (curve D) and in the presence (curves $\mathrm{A}-\mathrm{C}$ ) of $\mathrm{PH}^{+}$in the organic phase for various aqueous $\mathrm{CTAB}$ concentrations (A: $0 \mathrm{mM}$; $\mathrm{B}: 0.5 \mathrm{mM}$ and C: $2 \mathrm{mM}$ ). These CVs were recorded before photoelectrochemical experiments. The presence of surfactant in the aqueous phase destabilises the liquid-liquid interface. For a CTAB concentration of $0.5 \mathrm{mM}$, the current recorded at potentials between 0.3 and $0.65 \mathrm{~V}$ appears unstable, which is 
consistent with what was reported by Kakiuchi and colleagues [41]. At the higher concentration of CTAB, a fully resistive voltammogram was observed. Despite the interface instability in the cases where CTAB was present, photoelectrochemical experiments were carried out by the application of a potential of $+0.15 \mathrm{~V}$ for $50 \mathrm{~min}$. In the absence of $\mathrm{PH}^{+}$in the organic phase, no silica condensation was observed. In the presence of $\mathrm{PH}^{+}$, silica was condensed at the ITIES as a result of the acidification of the interfacial region. After 12 hours (at open-circuit potential and light off), silica was collected, cured at $130{ }^{\circ} \mathrm{C}$ for 16 hours and was then analysed by transmission electron microscopy (Figure 8). A wormlike structure was observed in all three cases, suggesting that mesopores can also be formed in the absence of surfactant. This had already been observed by Léonard and Su during the preparation of aluminosilicate materials by a bulk sol-gel process [42].

\section{Conclusions}

The photoactive quaternary ammonium cation (trimethylbenzhydrylammonium - $\mathrm{PH}^{+}$) was synthesised and characterised electrochemically at the ITIES. The photodecomposition of the $\mathrm{PH}^{+}$in the protic solvents was studied and the formation of diphenylmethanol in the aqueous phase, as one of the products of photolysis, was confirmed. The transfer and photochemical properties of $\mathrm{PH}^{+}$were then exploited to tune locally the $\mathrm{pH}$ of the aqueous phase. Due to the water reduction occurring at the aqueous counter electrode, the $\mathrm{pH}$ variation close to the interface could not be followed from bulk $\mathrm{pH}$ measurements. Iridium oxide modified Pt microdisc electrodes were thus used to study the $\mathrm{pH}$ changes at the local scale and the results have shown that the $\mathrm{PH}^{+}$transferred and photodecomposed in the aqueous phase increased dramatically proton concentration. The local pH drop, from ca. 6 to less than 2 was finally used to trigger the acidic condensation of silica at the ITIES.

\section{Acknowledgments}

The authors are grateful to the Agence Nationale pour la Recherche for the funding of the HYPERION project (grant number: ANR-14-CE14-0002-01). LP is grateful to SESAMES Doctoral school for PhD funding. Dr Chistelle Despas (ion chromatography expertise), Dr Manuel Dossot (lending of irradiation lamp) and Dr Neus Vilá (advice on the $\mathrm{PH}^{+} \mathrm{I}^{-}$synthesis) are gratefully acknowledged. Tyndall National Institute is thanked for the gift of the silicon membrane.

\section{References}


[1] A.N.J. Rodgers, S.G. Booth, R.A.W. Dryfe, Electrochem. Commun. 47 (2014) 17.

[2] G. Herzog, Analyst 140 (2015) 3888.

[3] S. Senthilkumar, R.A.W. Dryfe, R. Saraswathi, Langmuir 23 (2007) 3455.

[4] D. Hu, H. Wang, K. Gao, X. Jiang, M. Wang, Y. Long, Y. Chen, RSC Adv. 4 (2014) 57035.

[5] X. Jiang, K. Gao, D. Hu, H. Wang, S. Bian, Y. Chen, Analyst 140 (2015) 2823.

[6] H.J. Lee, P.D. Beattie, B.J. Seddon, M.D. Osborne, H.H. Girault, J. Electroanal. Chem. 440 (1997) 73.

[7] M.D. Scanlon, G. Herzog, D.W.M. Arrigan, Anal. Chem. 80 (2008) 5743.

[8] Y. Liu, J. Strutwolf, D.W.M. Arrigan, Anal. Chem. 87 (2015) 4487.

[9] Y. Chen, S. Bian, K. Gao, Y. Cao, H. Wu, C. Liu, X. Jiang, X. Sun, J. Memb. Sci. 457 (2014) 9.

[10] E. Smirnov, P. Peljo, M.D. Scanlon, H.H. Girault, ACS Nano 9 (2015) 6565.

[11] Y. Cheng, D.J. Schiffrin, J. Chem. Soc. Faraday Trans. 92 (1996) 3865.

[12] J. Guo, T. Tokimoto, R. Othman, P.R. Unwin, Electrochem. Commun. 5 (2003) 1005.

[13] M. Platt, R.A.W. Dryfe, E.P.L. Roberts, Electrochim. Acta 49 (2004) 3937.

[14] J.J. Nieminen, I. Hatay, P. Ge, M. a Méndez, L. Murtomäki, H.H. Girault, Chem. Commun. 47 (2011) 5548.

[15] A. Uehara, T. Hashimoto, R.A.W. Dryfe, Electrochim. Acta 118 (2014) 26.

[16] V. Mareček, H. Jänchenová, J. Electroanal. Chem. 558 (2003) 119.

[17] H. Jänchenová, K. Štulík, V. Mareček, J. Electroanal. Chem. 591 (2006) 41.

[18] L. Poltorak, G. Herzog, A. Walcarius, Electrochem. Commun. 37 (2013) 76. 
[19] L. Poltorak, G. Herzog, A. Walcarius, Langmuir 30 (2014) 11453.

[20] L. Poltorak, M. Dossot, G. Herzog, A. Walcarius, Phys. Chem. Chem. Phys. 16 (2014) 26955.

[21] L. Poltorak, K. Morakchi, G. Herzog, A. Walcarius, Electrochim. Acta (2015) 10.1016/j.electacta.2015.01.129.

[22] C. Johans, R. Lahtinen, K. Kontturi, D.J. Schiffrin, J. Electroanal. Chem. 488 (2000) 99.

[23] C. Johans, P. Liljeroth, K. Kontturi, Phys. Chem. Chem. Phys. 4 (2002) 1067.

[24] K. Lepková, J. Clohessy, V.J. Cunnane, J. Phys. Condens. Matter 19 (2007) 375106.

[25] P.S. Toth, Q.M. Ramasse, M. Velický, R.A.W. Dryfe, Chem. Sci. 6 (2015) 1316.

[26] C. Mousty, A. Walcarius, J. Solid State Electrochem. 19 (2015) 1905.

[27] J. Niedziolka, M. Opallo, Electrochem. Commun. 10 (2008) 1445.

[28] K.H. Jensen, J.E. Hanson, Chem. Mater. 14 (2002) 918.

[29] M. Etienne, J.-P.P. Moulin, S. Gourhand, Electrochim. Acta 110 (2013) 16.

[30] M. Etienne, S. Lhenry, R. Cornut, C. Lefrou, Electrochim. Acta 88 (2013) 877.

[31] M. Etienne, B. Layoussifi, T. Giornelli, D. Jacquet, Electrochem. Commun. 15 (2012) 70.

[32] M. Etienne, M. Dossot, J. Grausem, G. Herzog, Anal. Chem. 86 (2014) 11203.

[33] B. Ballesteros Katemann, A. Schulte, W. Schuhmann, Chem. Eur. J. 9 (2003) 2025.

[34] B.B. Katemann, W. Schuhmann, Electroanalysis 14 (2002) 22.

[35] K. Yamanaka, Jpn. J. Appl. Phys. 30 (1991) 1285.

[36] A.J. Bard, L.R. Faulkner, Eletrochemical Methods: Fundamentals and Applications, 2nd Ed, John Wiley and Sons, New York, 2001.

[37] R.A. McClelland, V.M. Kanagasabapathy, N.S. Banait, S. Steenken, J. Am. Chem. Soc. 111 
(1989) 3966.

[38] A. Takahashi, T. Natsume, N. Koshino, S. Funahashi, Y. Inada, H.D. Takagi, Can. J. Chem. 75 (1997) 1084.

[39] A. Fog, R.P. Buck, Sensors and Actuators 5 (1984) 137.

[40] S. Schacht, Q. Huo, I.G. Voigt-Martin, G.D. Stucky, F. Schüth, Science. 273 (1996) 768.

[41] T. Kasahara, N. Nishi, M. Yamamoto, T. Kakiuchi, Langmuir 20 (2004) 875.

[42] A. Léonard, B.-L. Su, Chem. Commun. (2004) 1674. 


\section{Figure captions}

Figure 1: Experimental set-up for local pH measurement above the liquid - liquid interface supported by an array of micrometer pores: (1) PTFE cell, (2) aqueous phase, (3) glass U-shaped tube filled with the organic phase and (4) organic reference supporting electrolyte, (5) the silicon wafer supporting array of $\mu$ ITIES ( $\varnothing=50 \mu \mathrm{m}$, membrane thickness: $100 \mu \mathrm{m}, 8$ pores, spacing pore center to center distance: $500 \mu \mathrm{m}),(6) \mathrm{UV}$ irradiation source, (7) double junction $\mathrm{Ag} / \mathrm{AgCl}$ reference electrode, (8) iridium oxide modified platinum microelectrode, (9) shear-force positioning system and (10) CCD camera used for visualization. Electrochemistry at the liquid-liquid interface was controlled with a platinum mesh as an aqueous counter electrode $\left(\mathrm{CE}_{\mathrm{aq}}\right)$, a silver - silver chloride reference counter electrode $\left(\mathrm{RE}_{\mathrm{aq}}\right)$ and a silver - silver chloride used as both organic reference and counter electrode ( $R E_{\text {org }} / \mathrm{CE}_{\text {org }}$ ).

Figure 2: (A) Cyclic voltammograms recorded for $\mathrm{PH}^{+}$transfer $\left(\left[\mathrm{PH}^{+}\right]_{\text {org }}=50 \mu \mathrm{M}\right)$ from 5 to $25 \mathrm{mV} \mathrm{s}^{-1}$. Arrow shows the scan direction of the forward scan. (B) Peak current versus $v^{1 / 2}$. Electrochemical cell 1.

Figure 3: $\mathrm{pH}$ values measured by potentiometry as a function of photoelectrolysis time in the absence (filled squares) or in the presence (circles) of $1 \mathrm{mM}$ of $\mathrm{PH}^{+}$in the organic phase. Bulk pH was measured at the beginning and at the end of each set of experiments (empty squares). Electrochemical cell 1. Inset: calibration curve for the $\mathrm{pH}$ probe before and after a series of experiments.

Figure 4: $\mathrm{pH}$ changes of the bulk aqueous solution as a function of the potential applied induced by the side reaction at platinum mesh counter electrode. $\mathrm{pH}$ was measured after 150 seconds (red circles) and 420 seconds (black squares) of chronoamperometric polarization. Inset: Photographs of the platinum counter electrode in the presence of the phenolphthalein in the aqueous phase when $E=-$ $0.4 \mathrm{~V}$ (left) or $\mathrm{E}=+0.4 \mathrm{~V}$ (right). Electrochemical cell 1.

Figure 5: Chromatograms of $\mathrm{PH}^{+}$photoelectrochemical degradation products (red curve) and of undegraded $\mathrm{PH}^{+}$(black curve). Photoelectrochemical degradation conditions were: $\mathrm{E}=+0.15 \mathrm{~V}$ for 50 min. Mobile phase flow rate: $3 \mathrm{~mL} \mathrm{~min}-1$. UV detection at $220 \mathrm{~nm}$. Inset: Control experiment of the photoelectrochemical experiment in the absence of $\mathrm{PH}^{+}$in the organic phase.

Figure 6: Cyclic voltammogram recorded for $1.01 \mathrm{mM} \mathrm{PH}^{+} \mathrm{TPBCl}^{-}$initially present in the organic phase is marked with red line. Black curve was recorded after 40 minutes of UV irradiation at open circuit potential. The direction of polarization is indicated by the dashed arrow. $v=10 \mathrm{mV} \mathrm{s}^{-1}$. 
Figure 7: $\mathrm{CV}$ in the presence of $\mathrm{PH}^{+}$for various concentrations of $\mathrm{CTA}^{+}(\mathrm{A}): 0 \mathrm{mM}$; (B): $0.5 \mathrm{mM}$; (C): 2 $\mathrm{mM}$ and in the absence of $\mathrm{PH}^{+}(\mathrm{D})$ using electrochemical cell 2. $v=5 \mathrm{mV} \mathrm{s}^{-1}$.

Figure 8: Transmission electron micrographs of the silica condensed at the ITIES in the presence of (A) $0 \mathrm{mM}$; (B) $0.2 \mathrm{mM}$ and (C) $2 \mathrm{mM} \mathrm{CTA}^{+}$.

Scheme 1: Schematic representation of the photolysis of $\mathrm{PH}^{+}$at $(\mathrm{A})$ open-circuit potential (ocp) and at (B) $E=+0.15 V$. 
Figure 1

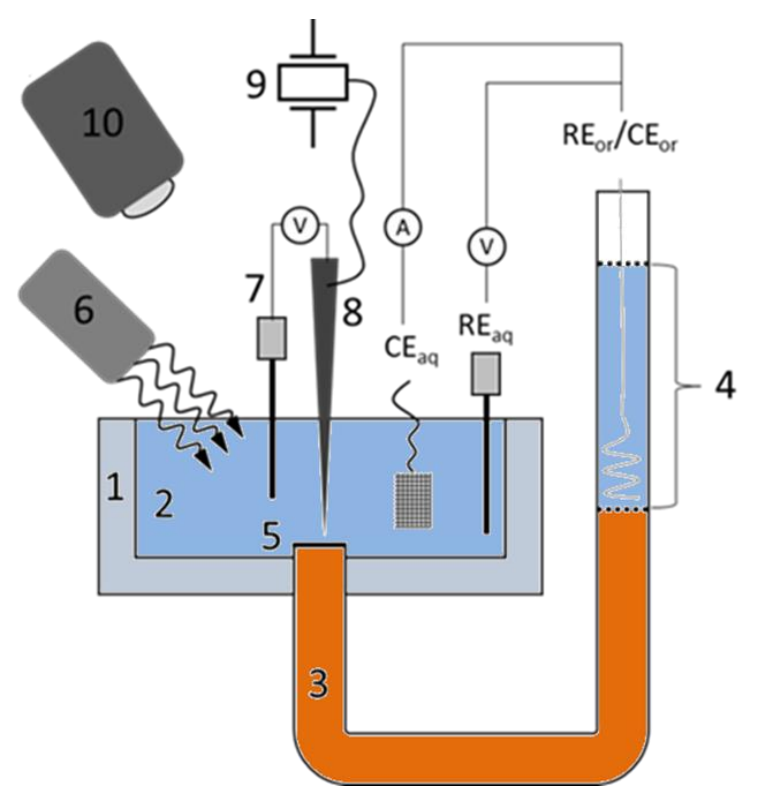


Figure 2
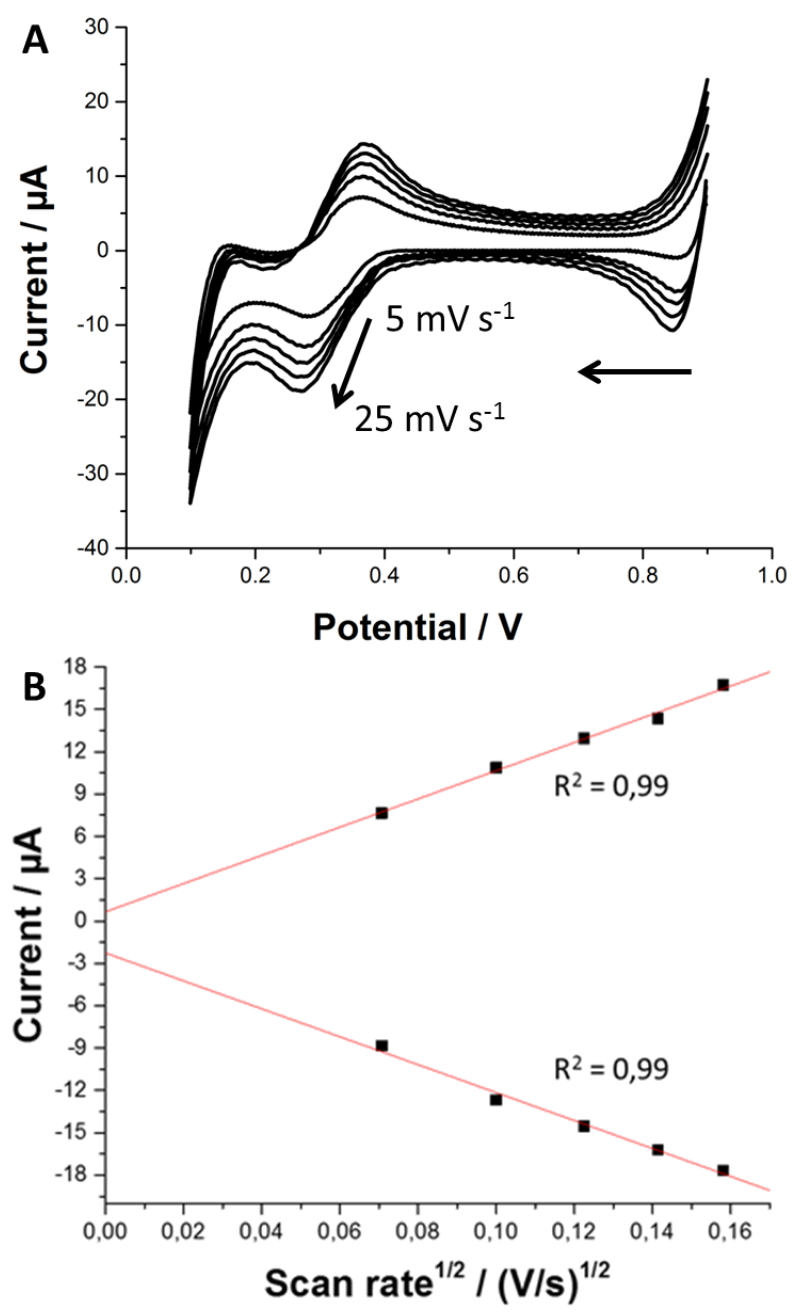
Figure 3

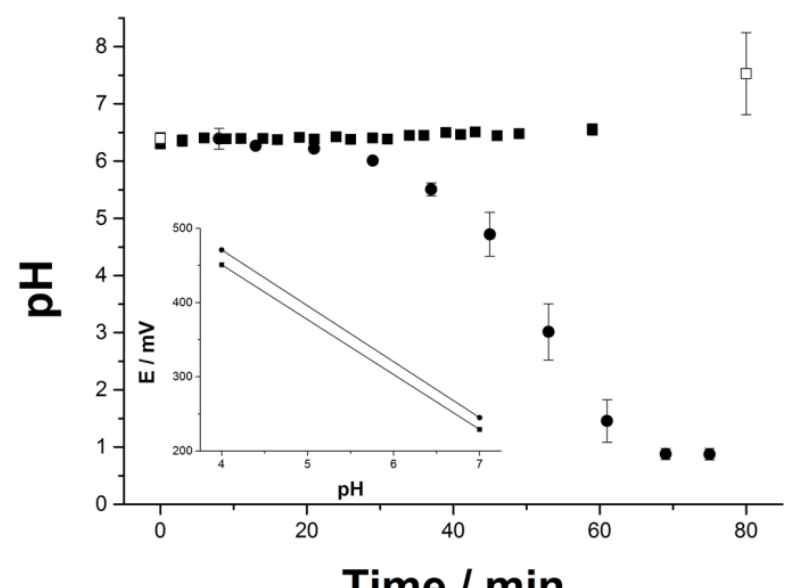

Time / min 
Figure 4

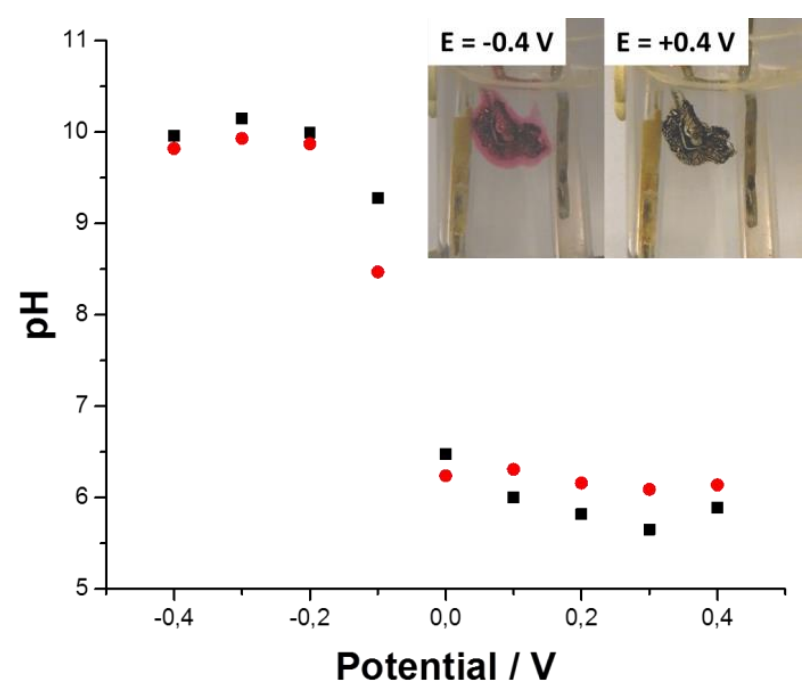


Figure 5

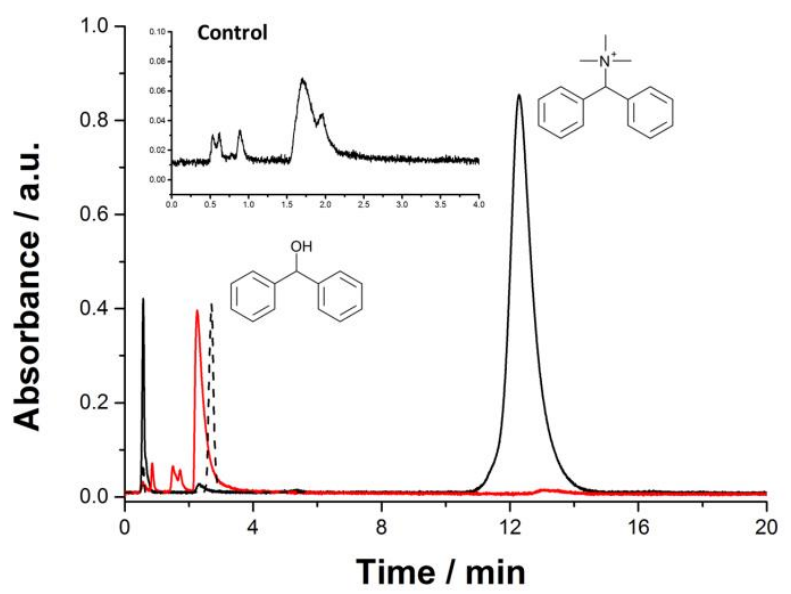


Figure 6

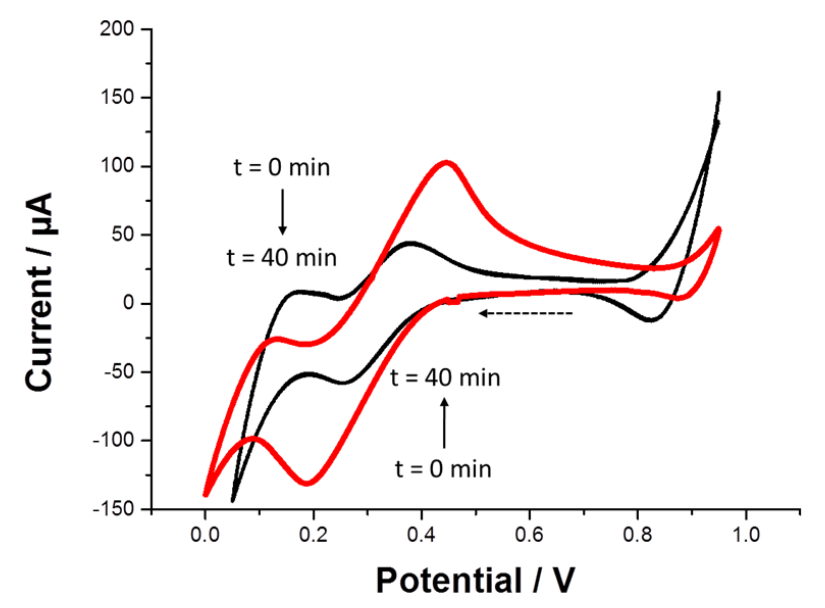


Figure 7

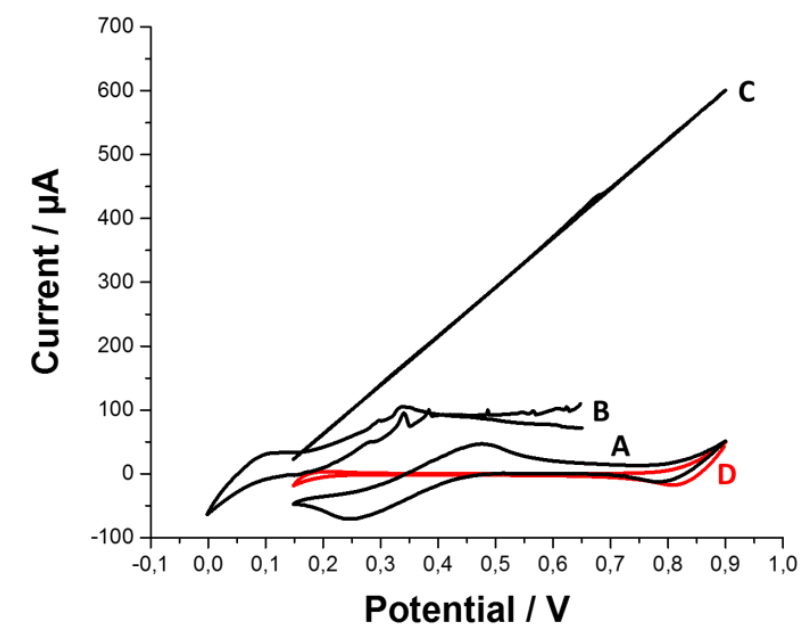


Figure 8

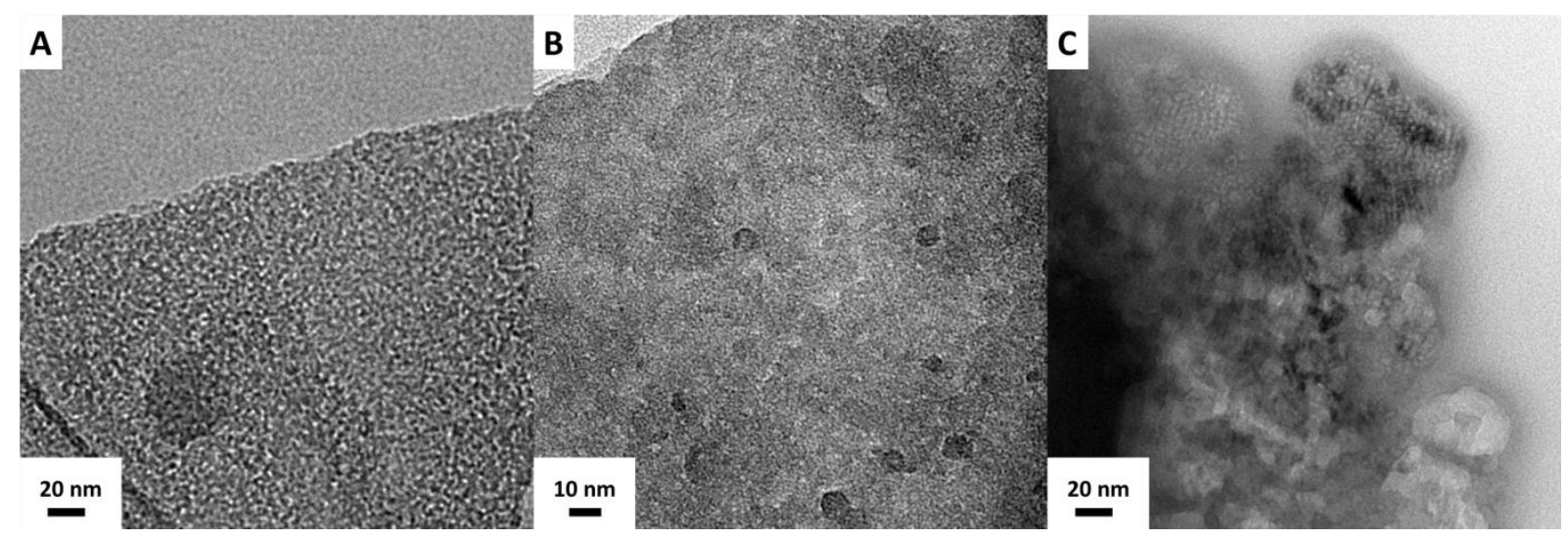


Scheme 1

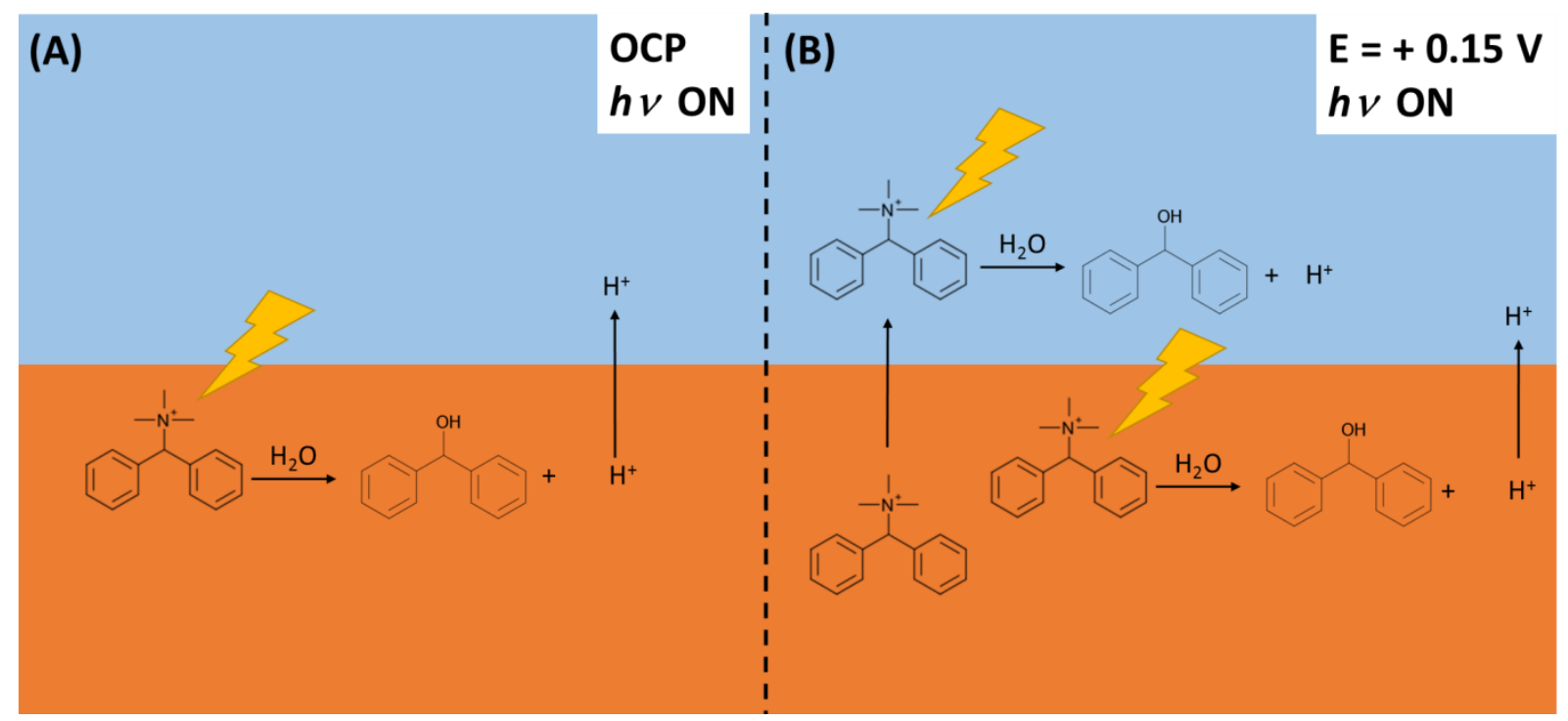

